\title{
The Importance of Motivation in Employees' Performance in Schools
}

\author{
Msc.Ortenca Kotherja \\ School Psychology/Organizacional, Work Location: Lecturer at the Faculty of Elbasan, Doctoral Process \\ Email: kotherja_ortenca@hotmail.com \\ Prof.Dr.Edmond Rapti \\ School Psychology, Work Location:Vice Rector of University of Tirana \\ Email: edi_rapti@yahoo.com
}

Doi:10.5901/jesr.2015.v5n2p117

\section{Abstract}

The school is an institution where the individual learns respective goals within the context of life and social norms. The main subject that helps in achieving the objectives that the school is teaching staff of each school. Motivating employees in educational institutions is one of the important issues given the responsibilities that they have the knowledge and skills of students. Motivational factors constitute an inflammatory effect which affects successfully achieve service that offers teaching staff in general and psychological services in general. Their performance is a concern for the whole society concerning the serving of knowledge and skills to students, using teaching methods, satifaksionin they profess to work etc. The large number of changes that occurred in the Albanian society has influenced directly in proccesin educational and work of teachers, managers, administrators in educational psychologists. This article is intended to acquaint us with the basic concepts and theories of motivation and the main factors affecting the performance of their work. To obtain productivity in any work environment is very important motivation in work performance of employees in the school institution. On the basis of knowledge to the understanding of these concepts and theories about them in this article suggest some recommendations on how to increase the motivation and performance of teachers. When the institution's goals coincide with individual goals can say that we are working with motivated staff that has a direct impact on increasing the level of education of the younger generation.

Keywords: Motivation, Performance, Psychological service, Psychological assessment

\section{Introduction}

Nowadays teachers must know to communicate and socialize with different cultures different linguistic and social contexts. Their work is such that dealing with pupils and students of different contexts socio-economic requires adjustment and patience on their part. A helpful in their work that they feel better is motivated deceased. Motivation comes from the Latin word "Mover" which means to move. Motivation is the activation or energization to move or to achieve a certain goal. Several scholars have given different ideas and definitions. For motivation Nelson and Quick (2003) stated that motivation is a process aimed at achieving a certain behavior. The topic of motivation as an important criterion in teaching process became apparent in the 1990s. Various studies (Dorney, 1998 Oxford, 1998) have shown that students put in the foreground commitment and enthusiasm of teachers in the hierarchy of needs that will help them to engage and be attentive to their teaching performance. Teacher motivation is one of the key issues by which are in charge of knowledge and learning in generations. Been understood that gives job satisfaction teachers, teaching staff in general makes it more productive and positive influence academic achievements of pupils, students (Mertler, 1992). Motivation promotes the activities and behaviors of people around the desire of achievements on education and the teaching aspect (Analoui, 2000). At work and in different contexts influencing motivation nature seen internal and external (Sansone \& Harackiewicz 2000). Motivational factors have a significant impact on job performance of employees in educational institutions. Being motivated affects a positive performance which enhances the academic level of education. The performance of teachers, psychologists at work includes the ability of teachers to integrate and show experience, teaching methods, teaching materials knowledge and skills to pupils and students both inside and outside the classroom. The great challenge of modern education is professional development of teaching staff in general, and plays a predominant role in educating the minds of pupils, students and the development of new generation personalities. Motivation refers to the psychological processes directly, activate, and support an action, or otherwise may be defined as 
one's inner desire to make an effort school. Provisional Institutions are the main premises on which educate the younger generation and the subject that helps in this, is the teaching staff in general. Their motivation in work environment directly affects the employee engagement. The motivation of employees at work is one of the most crucial in any institution especially institutions academic.

The aim of this article is to show the importance the basic concepts and theories of motivation and the main factors affecting the performance of their work.

The objective of this article:

a. To show the importance of motivational factors in the performance of the employees of the school institution

b. To demonstrate the importance of performance in the educational system

c. To show the importance of psychological services in motivation and performace of the employees of school.

\section{Methodology}

The methodology used in this study is a review of the literature by combining the concept of motivation and motivational factors with the performance. This connection is to show the importance that have the education and development of new generation. This combination is done to show the importance they have the education and development of education of the young generation.

\section{Motivation and the Importance of Its Factors of Employees at the School}

Motivation is the combination of the desire of a person and energy directed at achieving a goal. It can be internal to include a sense of satisfaction and feelings of achievement or external that includes rewards, punishments. Internal motivation comes from the person, from his personal activities which positively affects the behavior, performance and the benefits from it (Ryan \& Deci, 2000). External motivation in turn results from a number of factors such as bonuses, salary, prestige, and positive evaluation by others. Numerous studies have revealed internal factors and external motivator. In a study done in November of 2010 primary class teachers in Uganda was noted that internal factors motivating the teachers based on the satisfaction they receive from work to school, the satisfaction of teaching, career achievement and control over others. External factors that affect their motivation related prizes, working conditions, free nutrition, professional achievement awards and free medical check. Various theories have been set up to show the importance of motivational factors in the performance of the work of teachers in the school one of them is the set of Hezberg theory. Regarding internal factors motivating the individual tasks he described as internal motivation when they are characterized by key "motivational" responsibility, cooperation, varieties, opportunity Hezberg (1996). In relation to internal motivational factors associated individual tasks Hackamn. and Oldham (1976) identified various tasks as identifying tasks, tasks significantly, autonomy and feedback are based on the characteristics they exhibit generate internal motivation. In many literature in psychology motivational behavior is disposed externally to influence and satisfy psychological needs including the needs for autonomy and competence (Kasser \& Ryan, 1996). Pinder (1998) defines the work motivation "as a group of energetic forces that come internally and externally aimed arise human behavior by setting the duration, intensity and direction. The question that has preoccupied many researchers in motivating teachers is finding motivational factors that help teachers to do a "good job" and not just to say that the work we do "(Johnson, 2000). Various studies show a range of motivational factors that influence the performance of teachers. Eg. in his study Fremman \& Fremman (1994 cited by Jonson 2000) claimed that exposure to new ideas, availability of materials, the relationship and the quality of peer and receive positive feedback from students are very important factors in their work. In a study made in 2007 Davidson teachers in primary schools in Tanzania he claimed that the motivation of teachers is related to how teachers feel they are treated by the community, the conditions in which they live are related to salary and bonuses and conditions in which they work in school. This study shows the importance that should be given to conditions in which teachers work, the wages they receive to meet their economic side and the respect that they receive from individuals around them. In Albania there have been many changes, which has strongly influenced and educational aspect. Even though the development and socialization occurred in all aspect of society including education and see again that in this respect there is much to improve. In a study conducted at two public schools in the city of Elbasan in elementary and high system from interviews and questionnaires that were applied was observed that the need for motivation of these teachers was high-level view of the conditions in which they worked. Physical conditions that offer these schools as in summer and winter left to be desired. Didactic tools such as laboratories, computers, and library had to make teach much more motivator to display a good performance at work and in later years not display signs of burnout 
syndrome at work.

\section{Performance Concept and Its Importance in the Education System}

Performance is a multidisciplinary concept. It is a way of thinking and communicating for building and problem solving. The concept of perfomance itself involves both task performance and contextual performance. Borman and Motowidlo (1993) stated that the performance has two aspects task performance which refers to the ability of an individual with whom he / she performs an activity which contribute to the institution where the individual works and the other aspect is contextual performance which is not related to its technical contribution to the organization but that support organizational environment, social and psychological. In this context relates to the ability task performance and contextual performance is related to motivation and personality. Based on this understanding that teacher performance is directly dependent on motivational factors as though a teacher is proficient in his work if he / she does not feel motivated then the level of employment will fall as a result of lack of stimulus that he / she is at school by managers and students. Teacher performance means the role of teachers in students' learning, students as classroom and outside. This process involves the use of teaching materials, teaching methods, student rules, making a plan for classes, discussions with students, participation in various activities, care, counseling etc. Many studies have identified the most important variable in its quality teaching in academic achievements of pupils, students. The effect of teachers on student has more important than class size, fencing students, friends, fellow students from different social statuses, support economic (Sanders \& Horn, 1998). Given it should be understood that the performance of teachers at work in jobs should be given more attention by special. This can be achieved through assessments, tests different from administrators to discover how quality is the work of teachers with students during the academic year. In the past 35 years observer to see the performance of the teachers have studied the characteristics of the teacher and student attributes affecting their academic achievements in the country to study the characteristics of the resulting ineffective teaching. Nowadays researchers to see the performance of teachers focus on the fact that as teachers perform in the classroom and how this performance is followed in two respects as to the achievements of students and their assessments of pupils, colleagues, administrators and experts. A good performance is associated with meeting basic needs of employees that makes them feel motivated by giving energy and their desire to work in the specific case of teachers work with students that brings academic development as the best of the new generation.

\section{The Important of the Relationship on Motivation and Performance in the Work of Teachers}

Motivation and perfomance two concepts are closely related to each other. Many people believe that people who are more motivated in the workplace show a good performace motivated individuals are very fond of their work but this must be carefully managed so that they waste energy not be level higher because their work can often be counterproductive. Being motivated to work you need to know how to spending energies and skills to work as it directly affects the performance of the work. Teachers motivated, qualified are critical case to increasing productivity and quality of the process of education whose result is performance that they exhibit in their work with students, collaboration with colleagues and innovations they bring to the educational process. Satisfaction at work is one of the main needs that appeared visibly filling and fulfilling the needs of teachers at work which gives end and outcome of the work of teachers in relation to students and pupils. So in a working environment in case the academic institution exists a close relationship between motivation, satisfaction and performance. Motivation is what teachers need to perform better in their work. When a teacher felt motivated in the workplace, it is satisfied that visibly shows that in this academic environment their basic needs are met and that makes them perform much better and makes teachers to take responsibility for reductions and promotions that can display students during the academic year, makes them feel valued and this encourages a high level of productivity. It is very important that administrators, school leaders to develop methods that allow understanding of option rather motivational and not appearing to teachers.

\section{The Importance of Psychological Services in Motivation and Performance of Teachers}

It is very important that the working environment to be present and psychological services which has a great importance especially in the educational environment because it helps to solve various problems faced by teachers, students as academically and in that communication and cooperative. The psychologist works with teachers and suggest possible ways to solve various problems with students and encouraging them when to show signs of burnout syndrome as a result 
of stressful situations faced during the class in the classroom with students, the relationship colleagues etc. One of the benefits of the school psychologist is the work done by teachers to motivate students to engage in learning ((Reschly \& Christenson, 2006; Sinclair, Christenson, Evelo, \& Hurley, 1998), which helps to improve the academic performance of students at school. (Catalano, Haggerty, Oesterle, Fleming, \& Hawkins, 2004; Battistich, Schaps, \& Wilson, 2004). Also psychologist helps teachers in their work to design and implement academic interventions and helps the process behaviorally where interventions based support positive behavior by helping teachers to improve academic performance and reduce behavioral problems (Luiselli, Putnam, Handler, \& Feinberg, 2005; Nelson, Martell, \& Marchand-Martell, 2002) among students, during class, between colleagues in different collaborations and discussions etc.

\section{Conclusion}

As a conclusion we can emphasize the importance that motivational incentives during teacher work day. The performance of teachers is very important in the development of new generation and educational process. Motivation to learn is something personal to everyone individual but significantly affected by external factors is therefore important to emphasize the importance that the new generation educators in their work performance. As yet, the success of any educational process depends on teachers. Today and in the coming years is very important that administrators through various tests, observations, conversations and various meetings with the teachers to see and needs so that learning proccess be progressive steps. In Albania leaders should pay greater attention to the factors motivating the teachers based on the needs that they have in the premises where they work, to make assessments of the qualifications that they do during the academic year to reflect the physical conditions in which the work which although have occurred numerous changes again unmet basic needs such as physical conditions, as well as prizes awarded or those teachers during the academic year performing in the best way possible. It is also important to grow the number of school psychologists whose work is very important for the progress of education. When something broke the psychological contract between employee and organization leader must find what exactly causes this problem based on the symptoms that appeared to find a solution to this problem so that the institution / organization to progress and in this case the display a better performance in order to develop the process of educational .

\section{Suggestions}

Eligibility based on the work of teachers which will play an important role in minimizing stressful situations which often affects the emergence of burnout phenomenon.

Managers, administrators should standardize policies motivating teachers to reflect on the desire and needs of employees.

Managers often during various discussions should reward teachers showing the good work they have done.

Teachers are provided with proper security for the workplace.

Encouragement and cooperation among teachers is an important element of teacher motivation and performance. A good cooperation makes them feel happy and overshadowed signs of burnout effect to them. During the school year teachers in various projects it is important to cooperate, which helps in the exchange of ideas.

The existence of a significant need to recognize the importance of status and role that teacher education of the younger generation. As such it can be accomplished through print media, TV etj.e which helps to make them more safety, strength and feel important in the community

Teachers have a salary increase based on their qualifications, which will bring an increased level of motivation and increase performance at work. This will serve as a driving force other teachers who will be encouraged to motivate and work.

Government and educational systems must provide a basic matter of learning and teaching proccesit helping create suitable environments that helps in effective teaching and motivating for both teachers and students.

\section{References}

Analoui, F (2000). What motivates senior managers? The case of Romania. Journal of Managerial Psychology, Volume 15, Number 4 , pp: 324-340. University of Bradford, Bradford, UK

Bear, G. G., \& Minke, K. M. (Eds.). (2006). Children's needs III: Development, prevention, and intervention. Bethesda, MD: National Association of School Psychologists

Borman, W. C., \& Motowidlo, S. J. (1993). Expanding the criterion domain to include elements of contextual performance. In N. Schmitt 
\& W. Borman (Eds.), Personnel selection in organizations (pp. 71-98). Neë York: Jossey-Bass.

Catalano, R. F., Haggerty, K. P., Oesterle, S., Fleming, C. B., \& Hawkins, J. D. (2004). The importance of bonding to school for healthy development: Findings from the Social Development Research Group. Journal of School Health, 74, 252-261

Dornyei, Z. (1998). Demotivation in Foreign Language Learning: paper presented at the TESOL ' 98 Congress, Seattle. WA, March.

Freudenberg H.J. (1974), Staff Burnout "Journal of Social Issues", vol.30,n. 1,pp159-165

Freeman, J. (1999). Teaching gifted pupils. Journal of Biological Education, 43, 185-190.

Hackman, J.R., and Oldham, G.R. (1976). Motivation through the design of Work: Test of a theory. Organizational Behavior and Human Performance, 16, 250-279.

Kasser, T., and Ryan, R.M. (1996). Further examining the American dream: Differential correlates of intrinsic and extrinsic goals. Personality and Social Psychology Bulletin, 22, 280-287.

Johnson, K. E. (2000). Innovations in TESOL teacher education: A quiet revolution. In K.E

Luiselli, J. K., Putnam, R. F., Handler, M. Ë., \& Feinberg, A. B. (2005). Whole-school positive behavior support: Effects on student discipline problems and academic performance. Educational Psychology, 25, 183-198

Maslach, C. (1992) La syndrome del burnout . Il prezzo dell' aiuto agli altri, Assisi Cittadelle Editrice.

Mertler H (1992), Value make the Company. Harvard Business Review

Ryan, R.M., and Deci, E.L. (2000). Ëhen rewards compete with nature: The undermining of intrinsic motivation and self-regulation. See Sansone \& Harackiewicz, pp. 14-54.

Sanders, W.L. \& Horn, S.P. (1998).Research Findings from the Tennessee ValueAdded Assessment System (TVAAS) Database:Implications for Educational Evaluation and Research. Journal of Personnel Evaluation in Education,12(3),247-256.

Schaufeli B.W., Maslach C. E Marek T. (1993), Professional burnout: Recent developments in theory and research ,USA ,Taylor \& Francis. 
